\title{
Isolation and Identification of Lactic Acid Bacteria from Algerian Durum Wheat (Triticum Durum) Natural Fermented in Underground Silos Matmora "El-Hammoum" and their Antimicrobial Activity Again Pathogenic Germs
}

\author{
Mokhtari $\mathrm{S}^{\star}$, Kheroua $\mathrm{O}$ and Saidi D \\ Laboratory of Physiology and Food Security, Faculty of Natural Sciences and Life, University d' Oran 1 Ahmed Ben \\ Bella 31000, Algeria \\ *Corresponding author: Mokhtari S, Laboratory of Physiology and Food Security, Faculty of Natural Sciences \\ and Life, University d' Oran 1 Ahmed Ben Bella 31000, Algeria, E-mail: SARABIO113@YAHOO.FR
}

Citation: Mokhtari S, Kheroua O, Saidi D (2016) Isolation and Identification of Lactic Acid Bacteria from Algerian Durum Wheat (Triticum Durum) Natural Fermented in Underground Silos Matmora "ElHammoum" and their Antimicrobial Activity Again Pathogenic Germs. J Nutr Health Sci 3(4): 403. doi: $10.15744 / 2393-9060.3 .403$

Received Date: October 24, 2016 Accepted Date: November 21, 2016 Published Date: November 23, 2016

\begin{abstract}
In human nutrition, cereals constitute the basis of the food pyramid. In Algeria, storage of durum wheat (triticum durum) performs in underground silos matmour in some rural areas, these traditional methods rather simple conservation is an alternative for small producers; but starts to disappear because of settlement of the farming populations in the urban areas. In some conditions environmental: Infiltration of water and the increase in temperature will generate a fermentation of wheat grains stored in contact with the wall Matmora these fermentation can last 4-9 years to gives birth to new stable fermented product called El-Hammoum which comes from "Hmoum" meaning black, referring to the black color of fermented wheat. Is appreciated for its properties, organoleptic, nutritional and health. Durum wheat (triticum durum) fermented El- Hammoum has a long history in traditionally dishes Algerian. The aim of the study is the characterization microbiological of the El-Hammoum and that of Lactic acid bacteria which have health effect. The isolates of lactic acid bacteria obtained from El- Hammoum were identified by biochemical methods and by morph- physiological characteristics. Lactic acid bacteria dominated the microflora of these samples, especially the genera Lactobacillus and Lactococcus. The antimicrobial activity of strains was studied against indicator organisms (Staphylococcus aureus, E.coli, Pseudomonas aeruginosae, Bacillus subtilis, Proteus sp, and Candida albicans). The interactions study revealed that, strains isolated from El-Hammoum reduces the growth of indicator organisms.
\end{abstract}

Keywords: Durum wheat; Matmora; El-Hammoum; Natural fermentation; Lactic acid bacteria; Antimicrobial activity; Indicator organisms

\section{Introduction}

Wheat is one of the most cultivated cereals on earth and an important source of protein and phytonutrients for human consumption $[1,2]$. Storage in underground pit matmour is an archaic technique still can be used in some in rural environment [3]. Traditional storage method depends on climatic conditions including the rate of ambient humidity, and locally available materials; farmers use generally attics whose description and practical effectiveness varies from one region to another [4,5]. The storage of grain on the farm, if it doesn't always present an evident economic interest for the cereal producer, is often a necessity for the cattle breeder. A storage installation for grain at the farm is conceivable in general only for a sufficiently long time allowing the farmer to profit from his investisment. It allows him to control the rythm of the harvest. The farmer who stores stays master of his harvest. He's able to benefit from the advantages accorded by the storage firm to which he delivers (montyly increases) or equally well sell wren prices are the most attractive. The breeder who stores has already assured conservation of his own harvest [6].

During the process of fermentation, the wheat is subjected by the action of the micro-organisms and/or the enzymes, with desirable biochemical changes [7]. El-Hammoum natural wheat fermented in underground silos matmour is used for the preparation of a particular kind of couscous, which is the "Couscous el "El- Hammoum" or "black couscous", an Algerian food which features an acid taste, color brown, a little scared and a strong smell it gives off when it is steamed.

Underground storage for grain promotes the presence of multiple parameters (temperature changes, humidity, etc) spontaneous fermentation of wheat store this fermentation is provided by yeast and bacteria [8]. There are many bacteria that can live in conditions matmora; the other, on the contrary, there is an ideal environment; sap with its high content of sugars and proteins. Bacteria cause numerous changes in stored grain, the main one being the organic acid development, vitamins, and amino acid 
and the microbiological quality $[9,10]$. Several authors found that spontaneous fermentation for grain is lactic acid fermentation [11]. Lactic acid bacteria (LAB) have played along and important role in Food technology and have a long the history of use by man for food production and food preservation. Food contaminations by the pathogenic germ are a major problem for consumer's health in Algeria. The use of bacterial interactions is a new way to limit the pathogenic germs growth [12]. Say that during lactic fermentation, several bacterial species showed derivatives capacities of aflatoxines [13]. These beneficial micro-organisms must be integrated in processes of detoxification of food likely to be contaminated by the mycotoxins and to reduce the biodisponibility death toxins. The phenomena produced during fermentation touch the biochemical composition of corn where the principal components are useful like substrates for the microbial development and the enzymatic activities, by supporting the development of the lactic flora to the detriment of the other flora. This is very interesting because of the protective and beneficial effect of this flora on fermented corn. The preserving effects of lactic acid bacteria are due to the production of antimicrobial agents such as organic acids, hydrogen peroxide and bacteriocin [14-16]. The search for new strains of lactic acid bacteria that produce antimicrobial substances is a universal objective for the creation of new production of cultures starter with a high bio safety for fermented food $[17,18]$.

The aim of this work is the isolation of lactic acid bacteria and characterization of different groups of microflora, using classical methods: methods and by morph- physiological characteristics. The antimicrobial activity of strains was studied.

\section{Materials and Methods}

\section{Sample}

The durum wheat used in this study, was obtained from July 2007 harvest and was stored until May 2012 in a Matmora located in Ain Ferah ( $35^{\circ} 22^{\prime} 52^{\prime \prime}$ Nord, $0^{\circ} 47^{\prime} 02^{\prime \prime}$ Est of Mascara. Algeria); This underground pit has form of cavity, the cavity having a cylindro-conical shape, is found on a raised platform, designed to prevent harmful moisture rising to stored grain; and whose walls are lined with wheat straw. Large stones or large wooden forks are very hard insulating supporting the platform. The platform is then covered by with herbs. The fermented wheat (FWH) was retrieved from the walls. All samples were transferred to the laboratory under refrigeration and stored at $4{ }^{\circ} \mathrm{C}$ until their analysis (Table 1) (Figure 1 and 2).

\begin{tabular}{|c|c|}
\hline \multicolumn{2}{|c|}{ Indicator strains } \\
\hline Gram positive & Gram negative \\
\hline Staphylococcus aureus ATCC 6538 & Pseudomonas aeruginosa ATCC 10145 \\
\hline Bacillus Subtilis Subsp. Spizizenii ATCC 6633 & Escherichia coli ATCC 25922 \\
\hline
\end{tabular}

We also used yeast. Candida albicans; the stocks used in the tests belong to two groups of micro-organisms, which are the pathogenic ones and contaminants Table 1: Biological material
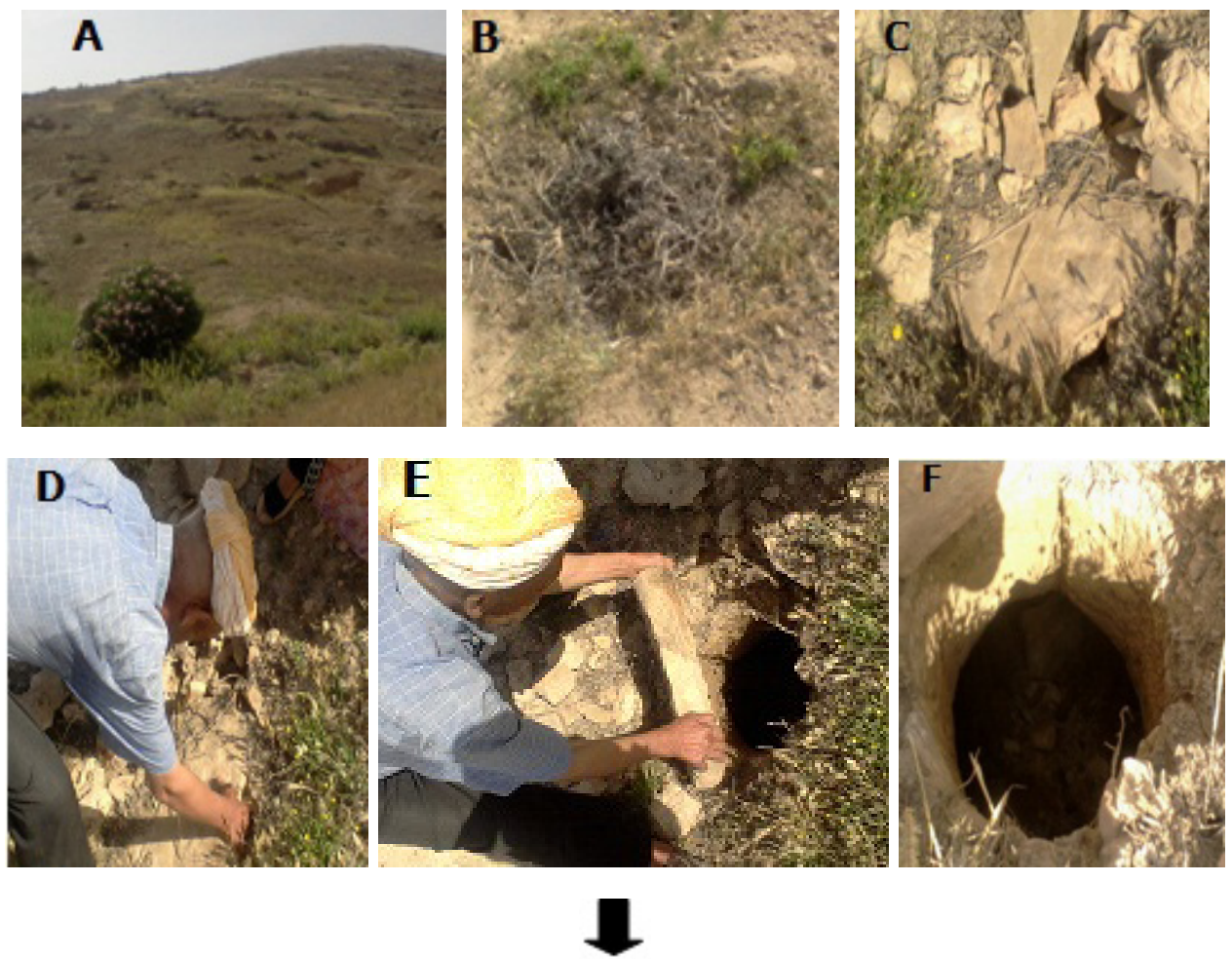


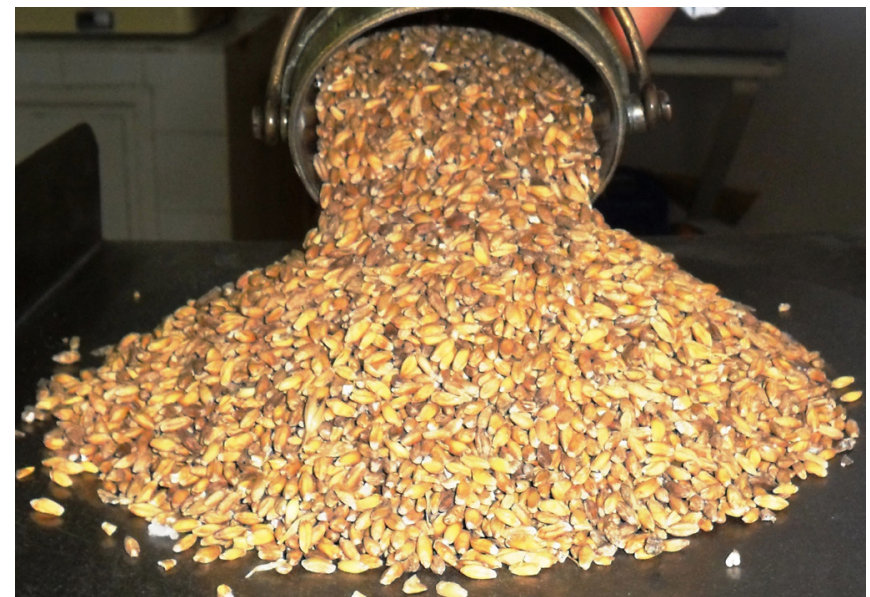

Figure 1: Picture of matmora and Fermented Durum Wheat (Photo Original, 2012)

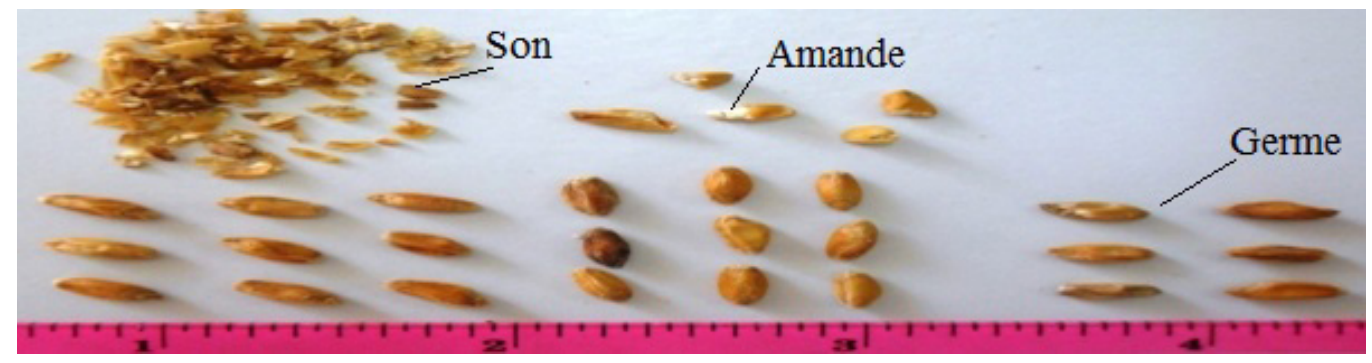

Figure 2: Picture of Fermented Durum Wheat El-Hammoum: Macroscopic Observation. (Photo Original, 2012)

\section{Isolation of Lactic Acid Bacteria}

The El-Hammoum sample (10 g) were diluted in $90 \mathrm{ml}$ TSE, homogenized by stomacher and serially diluted with TSE solution. Man Ragosa Sharpe Agar (MRS) was used for isolation of Lactobacillus, M17 Agar, and isolation of Lactococcus. MRS agar plates were anaerobically at $35{ }^{\circ} \mathrm{C}$ for $72 \mathrm{~h}$ by using Anaerocult for Lactobacillus; M17 is incubated aerobically at $30{ }^{\circ} \mathrm{C}$ for $72 \mathrm{~h}$ for Lactococcus. MSE incubated aerobically for $48 \mathrm{~h}$ at $35^{\circ} \mathrm{C}$ was used for used for isolation of leuconostocs [19].

To isolate LAB, colonies were randomly picked from each countable plate, was given to choose colonies with different macroscopic morphology. Isolates were reinoculated in MRS broth, incubated at $30{ }^{\circ} \mathrm{C}$ and checked for purity by streaking on MRS agar. Plates with pure cultures were used to test for cell morphology by phase contrast microscopy, Gram stain and catalase formation. Gram positive and catalase negative strains were selected.

\section{Characterization and Identification}

Preliminary Identification of the Isolates: Identification of the isolates at genus level was carried out following the criteria, using morphological methods. Cultures were examined microscopically for Gram staining and catalase production [20].

The following characteristics of the bacterial isolates were checked using standard protocols: production of gas from glucose, growth at different salt levels $(2,5,4$ and $6.5 \% ; 18 \% \mathrm{NaCl}), \mathrm{pH}$ tolerance, and growth at 10, 30, and $45{ }^{\circ} \mathrm{C}$. Growth at different temperatures was observed in MRS broth after incubation for 5 days. Supplemented test was performed for bacterial cocci and resistance at $63,5^{\circ} \mathrm{C}$ for $30 \mathrm{~min}$ was done in order to discard enterococcus bacteria Utilization of citrate was realised in Kempler and Mc Kay medium [19,21]. Production of acetone from glucose was determined using Voges-Proskauer test. Production of dextrane from sucrose was done in MRS agar and CO2 gas in Durham tube within MRS broth was checked from glucose [22].

The sugar profile of each strain was determined in MRS broth without lactose and meat extract and adjusted to $\mathrm{pH} 6.5$ as fermentation medium and bromocrésol purple (0.007\%) as indicator (MRS-BCP). Isolates were screened for their ability to ferment 13 different carbohydrates (Lactose, Amidon, Ellobiose, Glucose, Saccharose, Mannose, Galactose, Leuvulose, Sorbose, Adonitol Inositol, Duilactol, and Cellobiose).

Each tube receives $1 \mathrm{ml}$ of MRS-BCP medium, $100 \mu \mathrm{l}$ of microbial cell and $100 \mu \mathrm{l}$ of sugar solution. To ensure anaerobical condition $0,1 \mathrm{ml}$ of sterilized paraffin oil was added. The incubation was made at $30^{\circ} \mathrm{C}$ and the results read after 1 and 7 days of incubation [22].

\section{Storage of Isolates}

The short-term storage is made of pure strains on solid medium incline. After growth at optimal temperature, the cultures were 
maintained at $4{ }^{\circ} \mathrm{C}$ and the renewal of stem is done by transplanting every 4 weeks. The long-term conservation of the purified isolates is performed in a medium containing $70 \%$ skim milk $(0.05 \%$ enriched yeast extract and $0.05 \%$ glucose $)$ and $30 \%$ glycerol and stored at $-20^{\circ} \mathrm{C}[23,24]$.

\section{Screening of the Bacterial Isolates for Antimicrobial Activity}

Antimicrobial activity of the bacterial isolates against test pathogenic strains was determined by the agar-spot test. Each strain was grown in MRS broth incubated at $30^{\circ} \mathrm{C}$ for $16 \mathrm{~h}$ [25]. Aliquot $(10 \mu \mathrm{l})$ of the culture were seeded spot on agar containing $10 \mathrm{ml}$ of MRS medium. After $18 \mathrm{~h}$ incubation at $30^{\circ} \mathrm{C}$, the petri dishes were discovered with $5 \mathrm{ml}$ of Mueller Hinton agar inoculated with the indicator strain suspension to a final concentration of $10^{5} \mathrm{CFU} / \mathrm{ml}$. Isolates were screened for production of antimicrobial against: (Staphylococcus, aureus ATCC 6538; Pseudomonas, aeruginosa ATCC 10145; Escherichia, coli ATCC 25922; Bacillus Subtilis Subsp. Spizizenii ATCC 6633; Candida albicans). (Pathogenic bacteria were provided by Pasteur Institute of Algiers. Candida albicans by laboratory analyzes medicals Hospital Mascara, Algeria). The plates were then incubated for $24 \mathrm{~h}$ at a $37^{\circ} \mathrm{C}$, temperature conductive to growth of the indicator microorganism and were subsequently examined for zones of inhibition. After the incubation, inhibition zones formed in the medium were measured in millimeter $(\mathrm{mm})$. Inhibition was recorded as positive if the width $2 \mathrm{~mm}$ or larger [26,27].

\section{Results and Discussions}

In the present study, the isolates from El-Hammoum were given the symbol BFH (BFH1, BFH2, BFH3 .....and BFH8) = FWH (FWH1, FWH2, FWH3 ....... and FWH8).

These latter strains were identified to species level by methods as described by [28-30]. Description of culture morphological and microscopical characteristics was also included in (Table 2 and 3) (Figures 3, 4 and 5). In this connection, the fermentation of wheat stored in matmour has been powerful means for isolation of useful cultures applied for scientific, biotechnological and commercial purposes.

\begin{tabular}{|c|c|c|}
\hline Strain's code & Cell's form & Association type \\
\hline FWH1 & Short rod & In diplobacille and isolated \\
\hline FWH2 & Fine and long rod & In chain and palissade \\
\hline FWH3 & Short rod & Isolated and in diplobacille \\
\hline
\end{tabular}

Table 2: Morphological Characteristics of the Lactobacilli Isolated From El-Hammoum

\begin{tabular}{|c|c|c|}
\hline Strain's code & Cell's form & Association type \\
\hline FWH4 & cocci & In pairs or Chain \\
\hline FWH5 & cocci & In pairs or long Chain \\
\hline FWH6 & cocci & In pairs or short Chain \\
\hline FWH7 & cocci & In short or long Chain \\
\hline FWH8 & cocci & In pairs or short Chain \\
\hline
\end{tabular}

Table 3: Morphological Characteristics of the Lactococcus Isolated From El-Hammoum

A

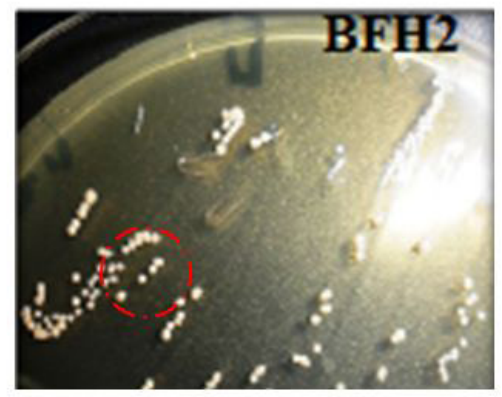

B

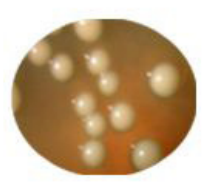

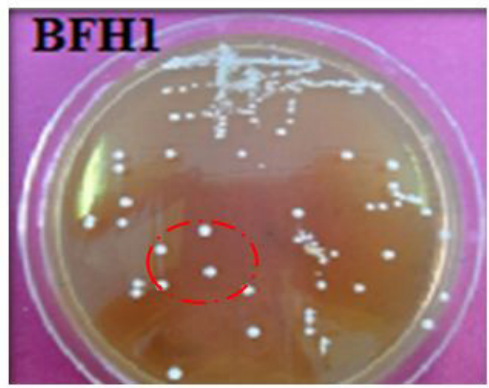

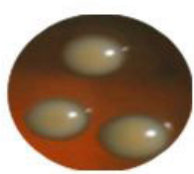

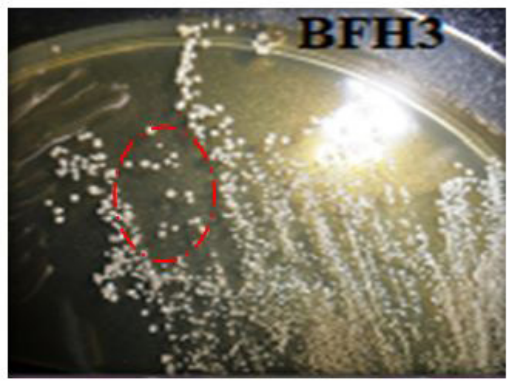

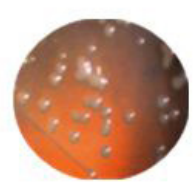



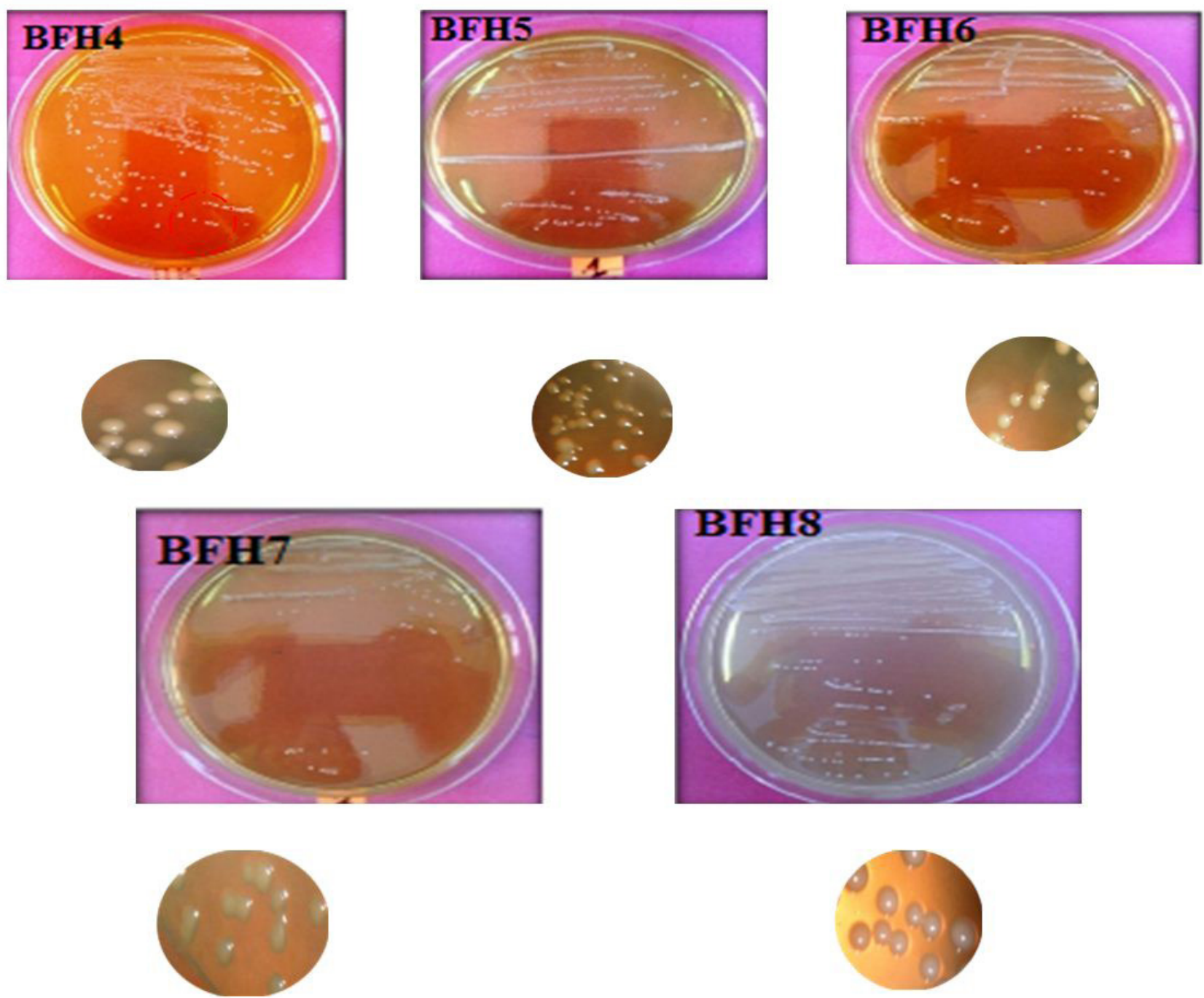

Figure 3: Observation Macroscopic Lactic Acid Bacteria Isolated From "El-Hammoum" (A). (B) Magnification (X20)
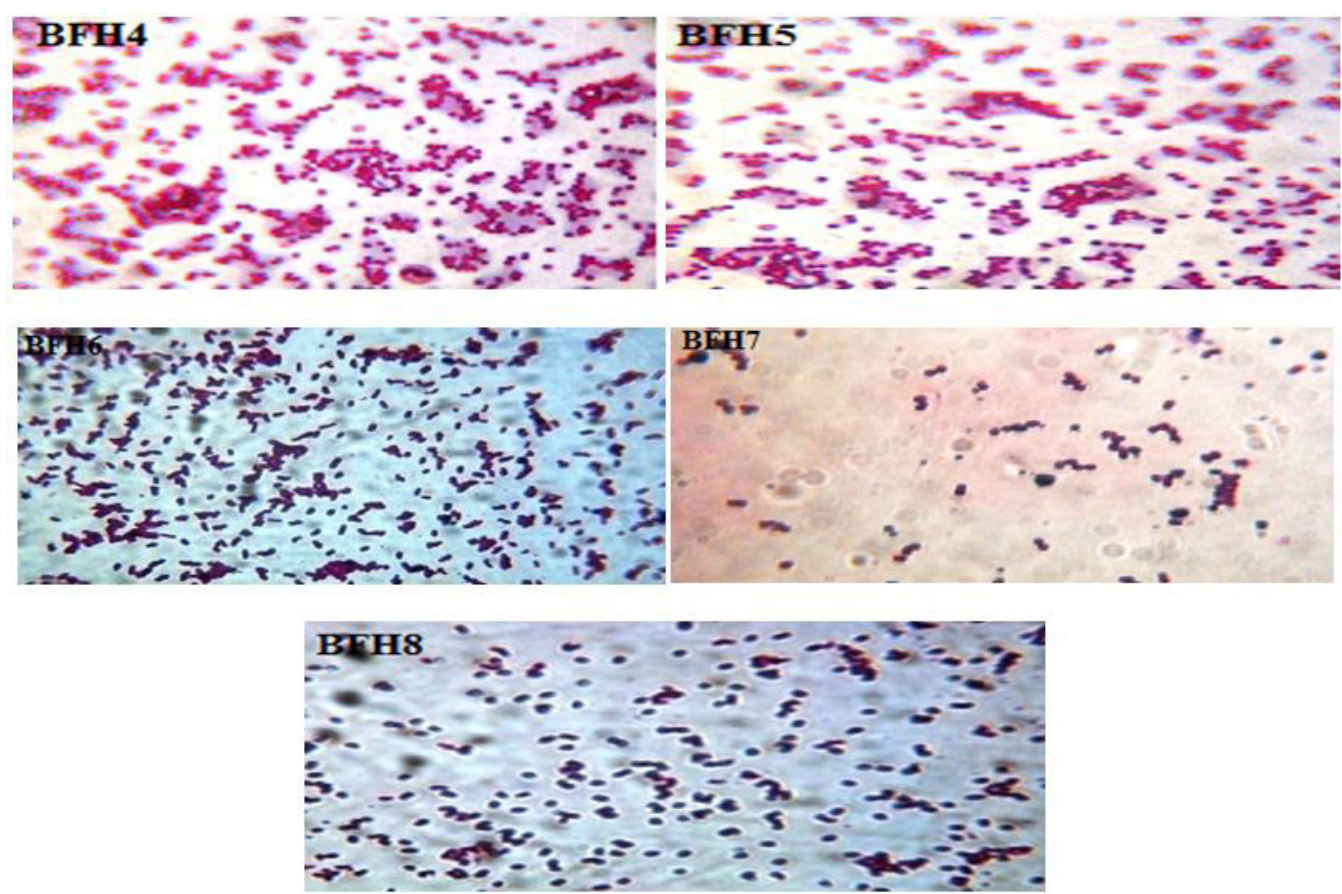

Figure 4: Observation Microscopic Strains FWH4, FWH5, FWH6, FWH7, FWH8 After Gram Staining (100X) 

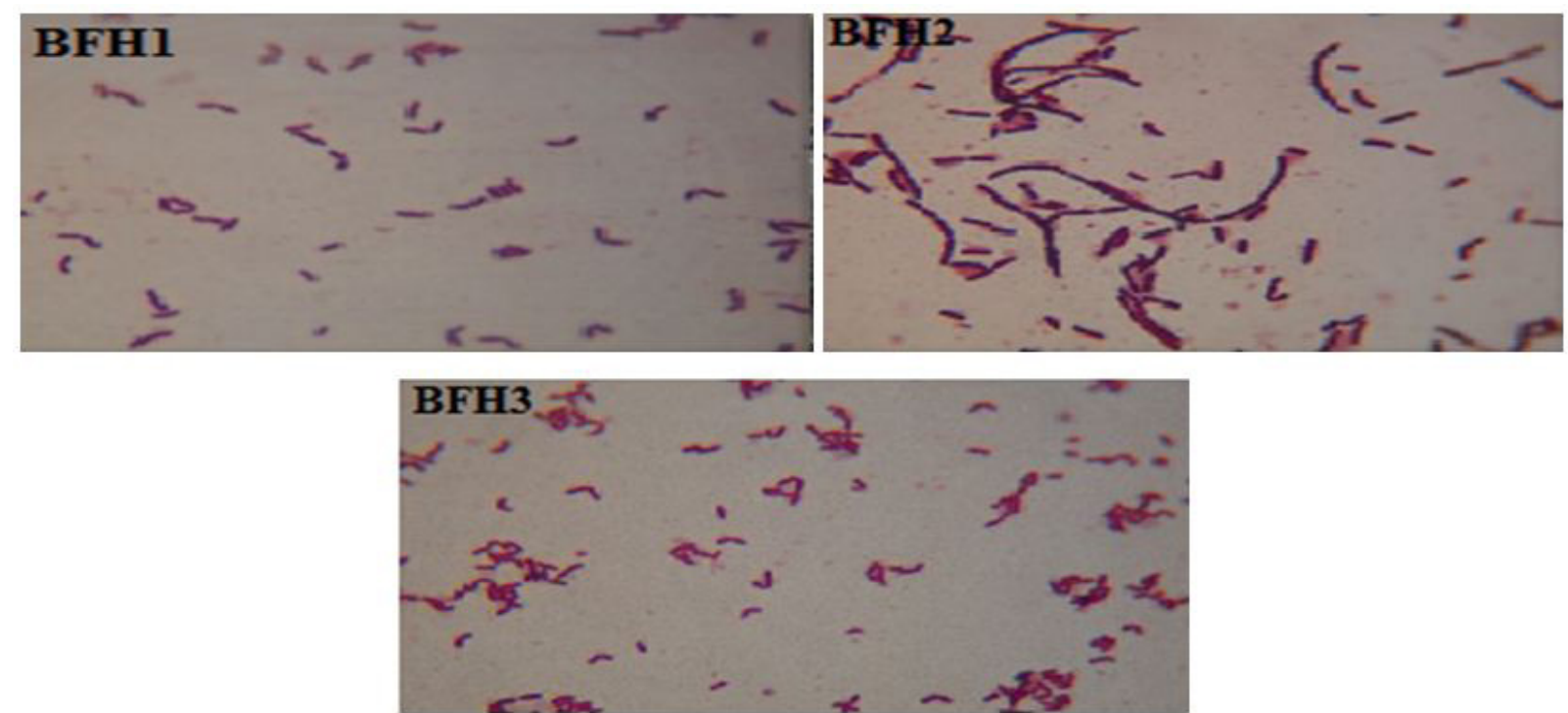

Figure 5: Microscopic Observation of Strain FWH1, FWH2, FWH 3 after Gram Staining (100X)

\section{Characterization of the Isolates}

\section{Physiological and Biochemical Test of Isolated LAB}

The strains retained give colonies, lenticular with a white or milky color, smooth surface and a regular circular were observed on solid medium. And other color, cream, or sometimes grayish yellowish edges regular, with a raised flat or slightly rounded medium or small. Microscopic observation of the isolates has identified Gram, shape and cell grouping mode. All isolates were grampositive with two different morphologies: shells grouped in chains, pairs, tetrads and bacilli (long and short) grouped in pairs and chains (Table 1 and 2). The completion of this test shows that our isolates (lactic cocci and lactobacilli) are catalase negative. The mobility of lactic acid bacteria is considered one of the tests for the differentiation of these bacteria, because they are generally motionless [31]. This test shows that all isolates (lactic cocci and lactobacilli) are not characterized by their encroachments of the medium from the inoculation; there is only a development along the sting, so our strains are immobile. For isolates of lactic cocci, Lactobacilli, the explored temperature range varies from 10 to $45^{\circ} \mathrm{C}$. Generally the growth of the whole strains is optimum at a temperature of $30^{\circ} \mathrm{C}$, which corresponds to the initial temperature of the isolation of lactic hulls. According to the growth intervals obtained, we can dir there are strains having a growth temperature minimum $37 \mathrm{C}$ and can grow at $3037^{\circ} \mathrm{C}$ and strains which have a wider temperature range $\left(30,37^{\circ} \mathrm{C}, 40^{\circ} \mathrm{C}, 45^{\circ} \mathrm{C}\right)$ and the last group includes strains with temperature maximum is $40.45^{\circ} \mathrm{C}$. a strain resistant to a temperature of $63.5^{\circ} \mathrm{C}$ As regards their growth to variations in salinity, all isolates are sensitive to concentrations of $\mathrm{NaCl}(6.5 \%)$ a blow. positive growth pros concentrations of $\mathrm{NaCl}(2.5,4 \%)$.

The classification of the isolates (Table 4) is made based on the morphological, biochemical and physiological. For lactic cocci characteristics presented by the isolates (FWH6, FWH8) are close to the genre Lactococcus, FWH4: Leuconostoc, FWH5: streptococcus, FWH7: enterococcus [32,33]. For lactobacilli isolates (FWH1, FWH2, and FWH3) appear to belong to the genus Lactobacillus [31,34,35]. In this work, all physiological and biochemical tests were similar as those obtained by [18,19,28-30]. The greater part of the isolates could be identified from "El-Hammoum". The results obtained in this study revealed that the "ElHammoum" presents an important source of lactic acid bacteria such: Genre Lactobacillus, Lactococcus, Leuconostoc, Enterococcus, and Streptococcus. Species determination was based on the metabolic profile, fermentation, obtained from different sugar to some kinds: (FWH1, FWH3): lactobacillus plantarum, (FWH4): Leuconostoc desctranicum, (FWH7): Enterococcus. Sp.

The main cereals used as raw material in the lactic fermentation in West Africa are maize, sorghum and millet. The dough fermented corn, one of the most popular fermented foods and starches, is used in the preparation of a wide variety of dishes as a staple food in Ghana, Nigeria, Togo and Benin, where they constitute a proportion important daily food ration. The lactic acid bacteria of the genus Lactobacillus, Streptococcus and Pediococcus are the most popular lactic acid bacteria, obtained from a spontaneous fermentation of grain by examples (Corn Name of the fermented product is consumed by Kenkey Ghana, Nigeria isolated strains (Lactobacillus brevis, Lactobacillus plantarum, Lactobacillus acidophilus, Lactobacillus fermentum). Lactobacillus fermentum, Lactobacillus strains, Pediococcus sp, are isolated from of Ogi- baba (based products Corn, fermented sorghum) in the countries Benin, and Togo. In this section we present studies confirm our results in present study [36]. De Vuyst and Vancanneyt [37]. Shows that the isolation of novel taxa mainly depends on the cultivation approach used selective incubation media and conditions. The identification of isolated strains needs a combination of phenotypic and genotypic methods (Figures 6, 7, 8, 9, 10, $11,12,13)$. 

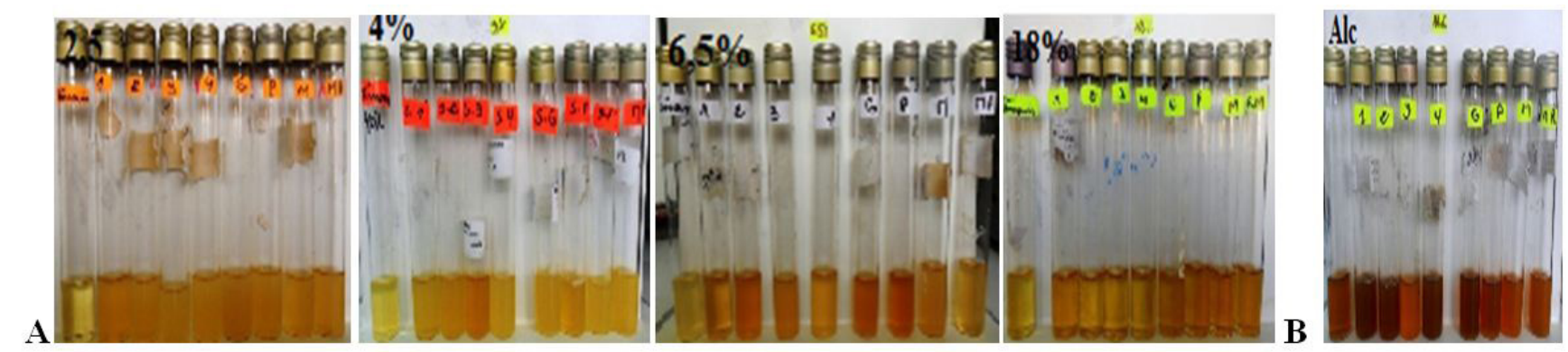

A: with $\mathrm{NaCl} 2,5 \%-4 \%-6,5 \%-18 \%$ concentration deferent

B: Growth of the lactic bacteria in alkaline medium

Figure 6: Growth of the stocks insulated in the environment hostile
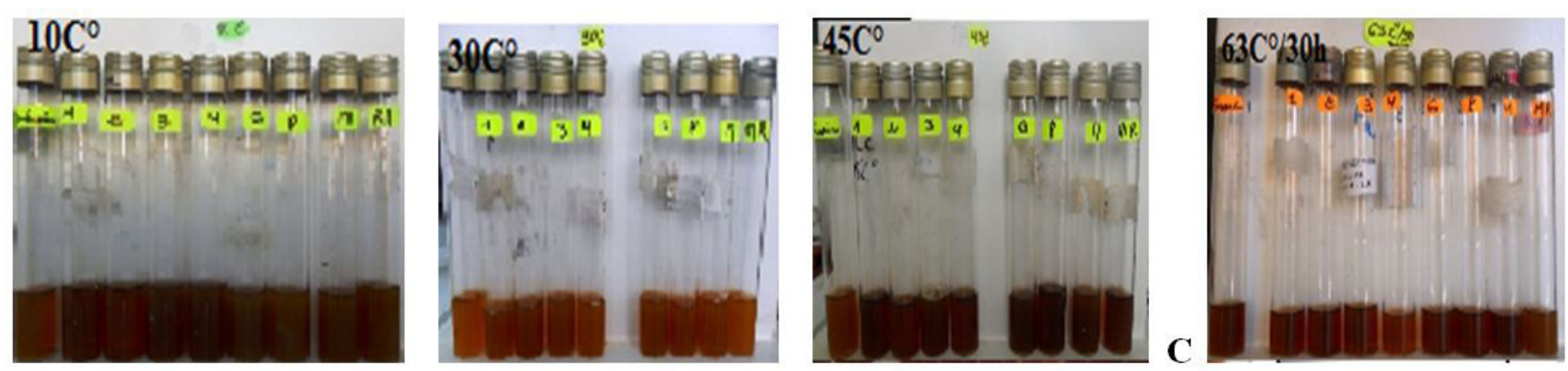

C: Growth of the stocks insulated treated by temperatures $63,5 \mathrm{C}$ during $30 \mathrm{~min}$

Figure 7: Growth of the stocks insulated with deferent's températures: $10 \mathrm{C}, 30 \mathrm{C}$ and $45 \mathrm{C}$
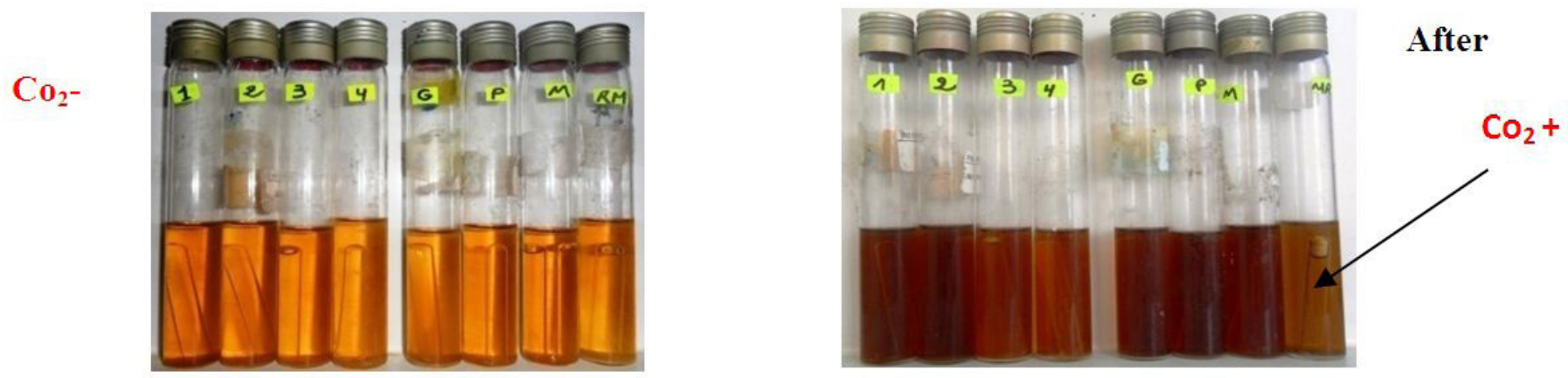

Figure 8: Various metabolic types of the stocks tested, observed after $48 \mathrm{H}$ of incubation
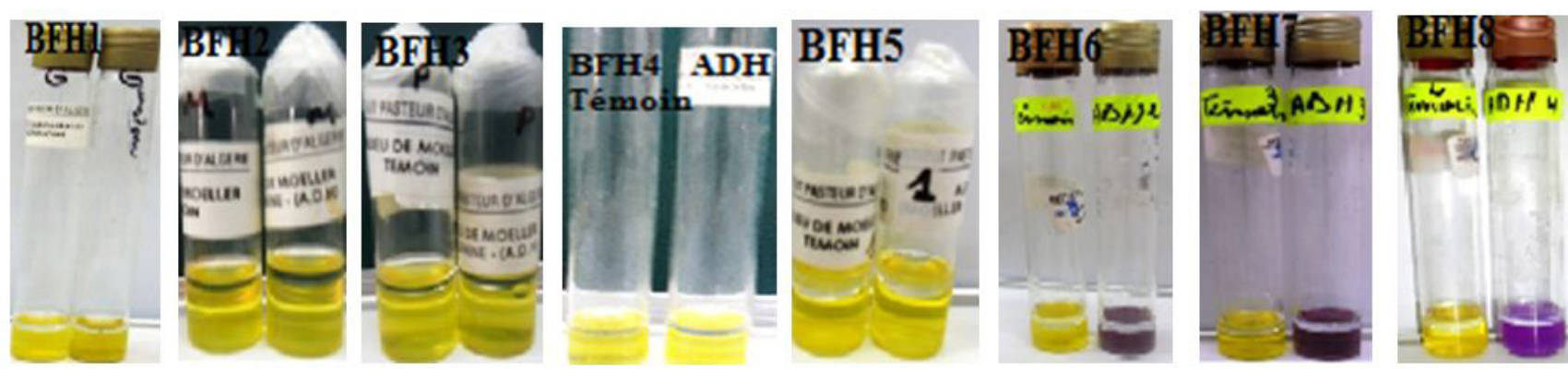

Figure 9: Results $\mathrm{ADH}$ of the stocks tested, observed after $48 \mathrm{H}$ of incubation
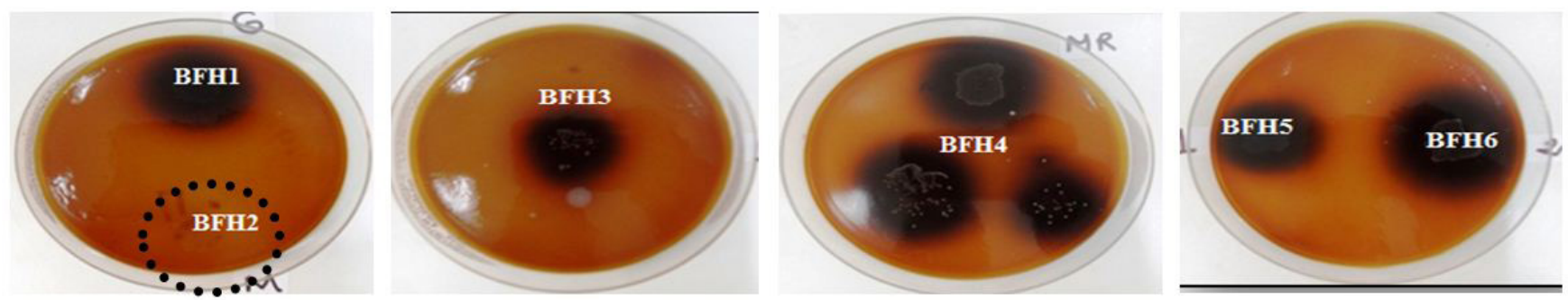


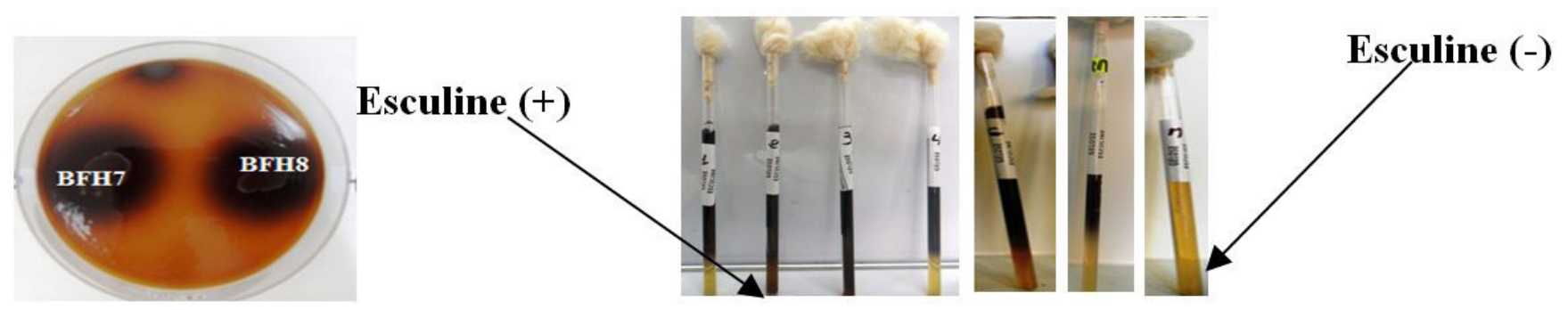

Figure 10: The test of the search for Bile the asculine after $48 \mathrm{H}$ of incubation
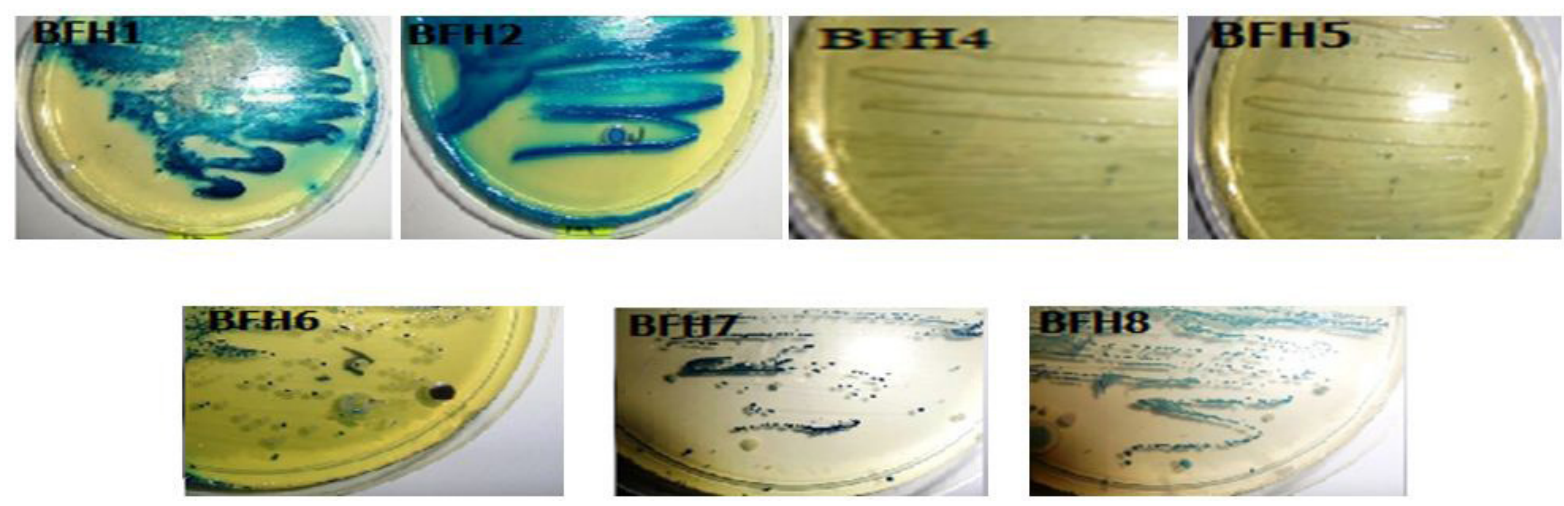

Figure 11: The test of the search for citrate after $48 \mathrm{H}$ of incubation
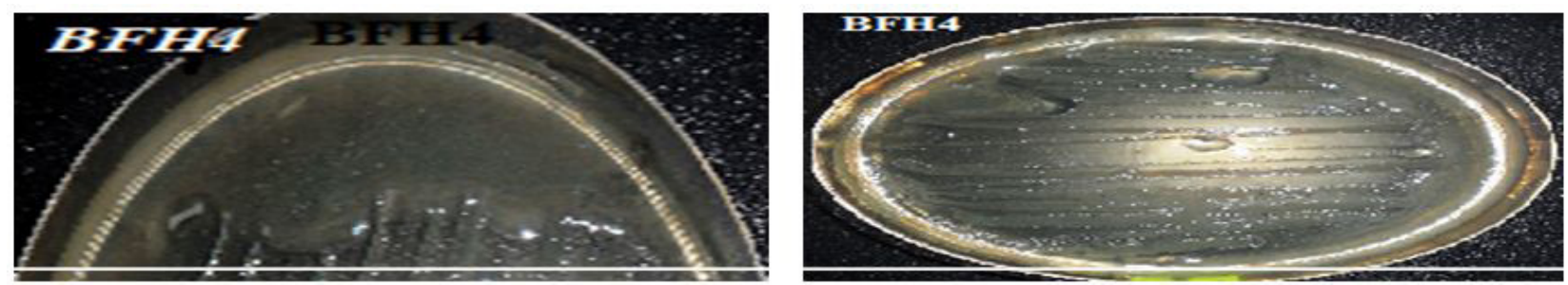

Figure 12: Test of dextrane production by the stocks insulated after $48 \mathrm{H}$ from incubation
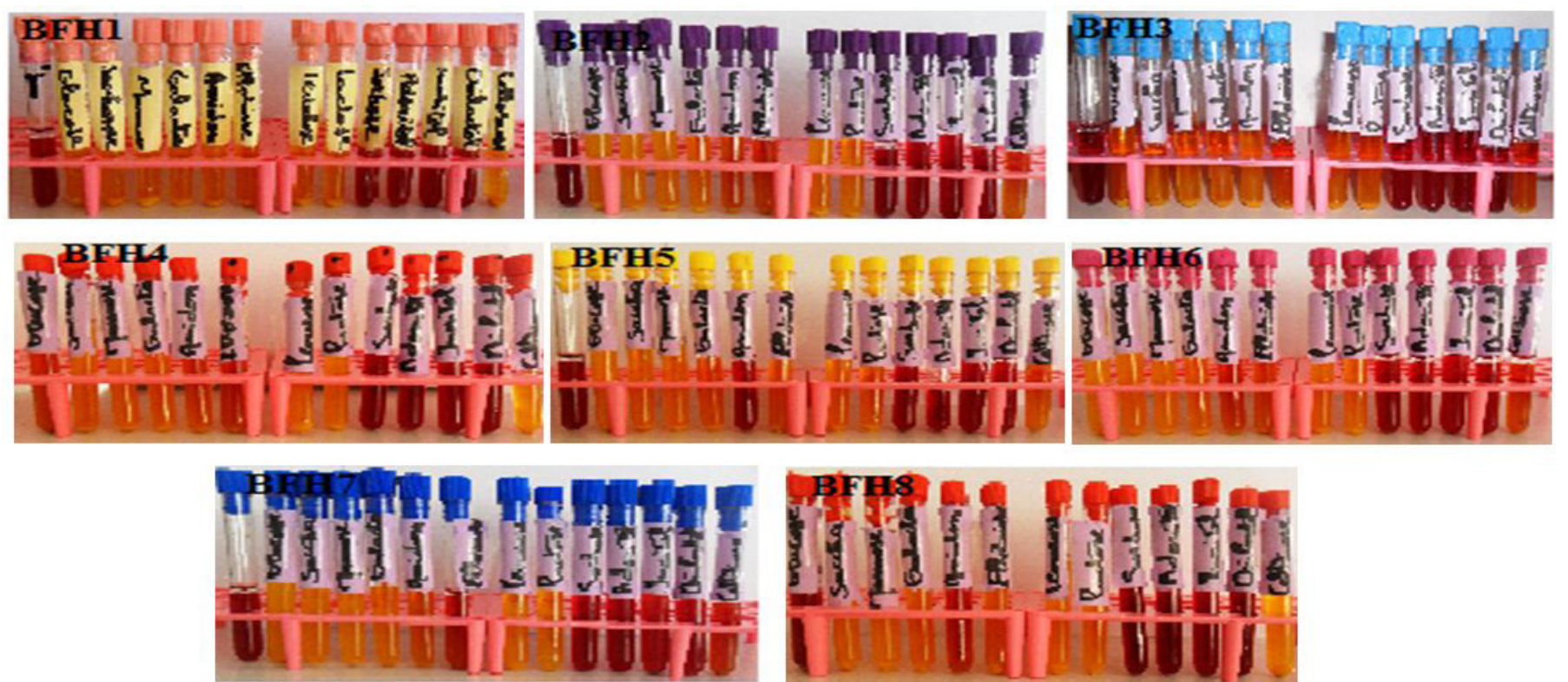

Figure 13: Result of profiles fermentaires of isolates' of El-Hammoum

Detection of Antimicrobial Producing LAB: All the isolates retained were tested for their antimicrobial activity (Table 4) (Figure 14). The zones of inhibition in the spot method test were more easily visualized. Generally the median values recorded by measuring the diameter of the inhibition zones, show that the lactic acid strains were tested for their capability to inhibit the growth of six indicator of Gram positive and negative bacteria (Table 4) (Figure 6), showed their antagonistic capacity towards these pathogenic bacteria by producing antimicrobial substance in the culture medium. Title has comparative, the activity antimicrobic of insulated 
is more significant on the fungic stock of Candida albicans by contribution with the bacteria, strongly inhibition growth of Staphylococcus aureus was obtained by all isolated strains, Lactobacillus plantarum and Streptococcus. Lactobacillus expressed an inhibition growth of Bacillus subtilis and Escherichia coli, Pseudomonas aeruginosa with various diameters. Inhibition of food-borne pathogens such as Staphylococcus aureus by the lactic microbial flora was announced by Heikkila and saris [17]. Lactobacillus plantarum has also antimicrobial property against Candida Albicans. Streptococcus inhibits the growth of Pseudomonas, and Candida albicans. The growth of Staphylococcus aureus, Pseudomonas is prevented also by Leuconostoc desctranicum. Moreover the second highest antimicrobial activity of all isolated strains tested were both against to Candida albicans. Candida albicans is the only yeast taken in our etude. Is mainly at the origin of the candidose. It is a micro-organism which resists antibiotic plusieurs the conditions which supporting an infection with Candida any disease being able to affect the state general of an individual. According to many studies all lactic acid bacteria isolate identified from traditional fermented dairy products and traditional fermented foods have positive inhibition toward pathogenic bacteria. This inhibition is due to an inhibiting substance like organic acids. Our results are also partly consistent with the work undertaken by who reported that Lactobacillus plantarum isolated from Algerian goat's milk to a significant inhibitory activity agains Staphylococcus aureus [38]. Performed by other traveaux, shows the sensitivity of Staphylococcus aureus by lactic acid bacteria isolated from fermented milk trditionel "RAIB” [12].

Our results are partly similar to those of [39]. Who report the antimicrobial activity of Streptococcus, Leuconostoc, and Lactobacillus isolated from deferent areas: camel milk, cow, and goat again Escherichia coli, Staphylococcus aureus, Candida albicans, and a major activity proved by, Lactobacillus and Lactococcus.

According to the work groups $[22,38,40]$. The difference in inhibition is due to substances secreted by strains lactic what was considered a line of defense against pathogenic bacteria possible contaminants products fermented. Similarly, studies by [15,41,42]. Confirms that most of the lactic acid bacteria are able to influence the growth and development of other species of pathogenic bacteria by the production antimicrobial substances such as organic acids, the hydrogen peroxide, diacetyl and bacteriocins, etc [43]. The phenomena produced during fermentation affect the biochemical composition of wheat where the main components are used as substrates for microbial growth and enzyme activities, promoting the development of lactic flora at the expense of other flora. This is very interesting because of the protective and beneficial effect of this flora on the fermented wheat, for the inhibition of pathogenic microorganisms, the production oforganic acids and antimicrobial substances, the degradation of toxic compounds and synthetic flavorings [44]. The lactic bacteria isolated and identified show a capacity to inhibit pathogenic bacteria tested. These pathogenic bacteria are known like contaminant of the traditional fermented products and traditional fermented foods. It is essential to know that the lust of lactic acid bacteria for fermentation process is due to many of their properties considered interesting. Among these, mention may be made probiotic effects and / or prebiotics they can impart to a food [45]. Fermented foods help also to reduce the duration and severity of childhood diarrhea [37]. The many properties conferred by the lactic fermentation at the matmora can afford to say that El-Hammoum has acquéri probiotic and prebiotic properties (Table 5).

\begin{tabular}{|c|c|c|c|c|c|}
\hline Isolate code & $\begin{array}{c}\text { Staphylococcus } \\
\text { aureus ATCC 6538 }\end{array}$ & $\begin{array}{c}\text { Pseudomonas aerugi- } \\
\text { nosa ATCC 10145 }\end{array}$ & $\begin{array}{c}\text { Escherichia coli } \\
\text { ATCC 25922 }\end{array}$ & $\begin{array}{c}\text { Bacillus Subtilis Subsp. } \\
\text { Spizizenii ATCC 6633 }\end{array}$ & $\begin{array}{c}\text { Candida } \\
\text { Albicans }\end{array}$ \\
\hline FWH1 & ++ & - & - & + & ++ \\
\hline FWH2 & - & - & - & +++ & + \\
\hline FWH3 & ++ & - & - & - & ++ \\
\hline FWH4 & ++ & + & - & + & - \\
\hline FWH5 & +++ & ++ & - & + & ++ \\
\hline FWH6 & +++ & +++ & ++ & + & +++ \\
\hline FWH7 & ++ & ++ & - & + & ++ \\
\hline FWH8 & ++ & ++ & + & + & ++ \\
\hline
\end{tabular}

Key: Inhibition zone Diameter: - = no inhibition; +: 2-9 mm; ++: 10-12mm; +++ : >12. FWH: fermented wheat Hamoum; ATCC: American Type Culture Collection

Table 4: Screening of Bacterial Isolates for Antimicrobial Activity against Test Pathogens

\begin{tabular}{|c|c|c|c|c|c|c|c|c|c|c|c|c|c|c|c|c|c|c|c|c|c|c|c|c|c|c|c|c|c|c|c|}
\hline 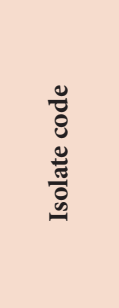 & 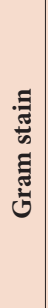 & 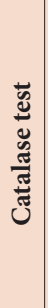 & 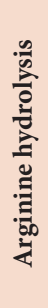 & 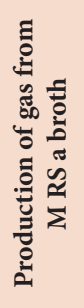 & 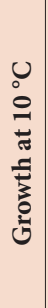 & 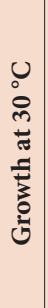 & 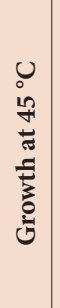 & 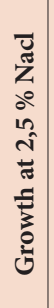 & 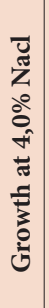 & 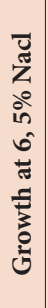 & 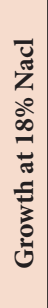 & 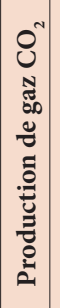 & 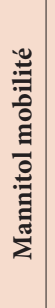 & 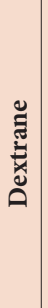 & 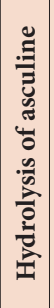 & 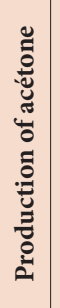 & 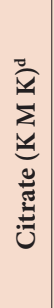 & 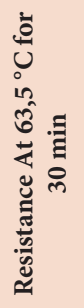 & - & $N$ & $m$ & $r$ & in & 6 & $n$ & $\infty$ & $a$ & 인 & $=$ & $\simeq$ & 2 \\
\hline a FWH1 & + & - & - & - & + & + & - & + & + & - & - & - & - & $\mathrm{N}$ & + & + & + & $\mathrm{N}$ & + & + & + & + & +- & + & + & +- & - & - & - & - & + \\
\hline b FWH2 & + & - & - & - & + & + & +- & + & + & - & - & - & - & $\mathrm{N}$ & - & + & + & $\mathrm{N}$ & + & + & + & + & +- & +- & + & + & - & - & - & - & -+ \\
\hline c FWH3 & + & - & - & - & + & + & - & + & + & - & - & - & - & $\mathrm{N}$ & + & +- & +- & $\mathrm{N}$ & + & + & + & + & +- & + & + & +- & - & - & - & - & + \\
\hline
\end{tabular}




\begin{tabular}{|c|c|c|c|c|c|c|c|c|c|c|c|c|c|c|c|c|c|c|c|c|c|c|c|c|c|c|c|c|c|c|c|}
\hline 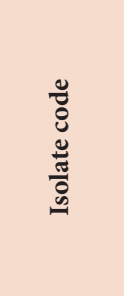 & 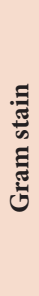 & 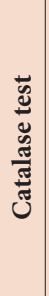 & 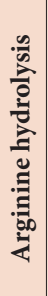 & 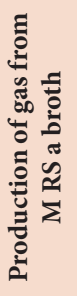 & 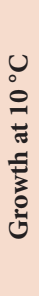 & 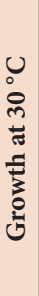 & 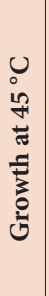 & 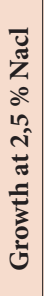 & 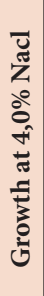 & 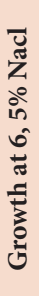 & 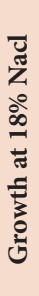 & 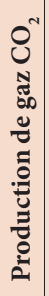 & 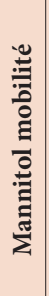 & 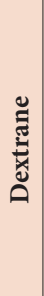 & 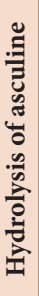 & 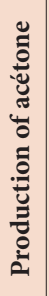 & 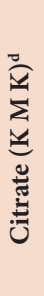 & 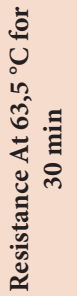 & - & N & $m$ & 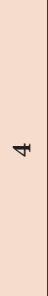 & in & 0 & $n$ & $\infty$ & $a$ & 음 & $\exists$ & I & 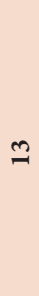 \\
\hline d FWH4 & + & - & - & + & + & + & + & + & + & - & - & + & - & + & + & +- & - & - & + & + & + & -+ & +- & +- & + & + & - & - & - & - & + \\
\hline e FWH5 & + & - & - & - & - & + & + & + & - & - & - & - & - & $\mathrm{N}$ & + & + & - & + & + & + & + & + & - & + & + & + & - & - & - & - & +- \\
\hline f FWH6 & + & - & +- & - & + & + & + & + & + & - & - & - & - & $\mathrm{N}$ & + & + & +- & - & + & + & + & + & +- & +- & + & + & - & - & - & - & +- \\
\hline g FWH7 & + & - & + & - & + & + & + & + & + & + & - & - & - & $\mathrm{N}$ & + & + & + & - & + & + & + & + & + & +- & + & + & - & - & - & - & +- \\
\hline h FWH8 & + & - & +- & - & + & + & + & + & + & - & - & - & - & $\mathrm{N}$ & + & + & + & - & + & + & + & + & +- & + & + & + & - & - & - & - & + \\
\hline
\end{tabular}

Key: + = Positive reaction, - = negative reaction, $\mathrm{N}=$ not determined, 1: Glucose, 2: Saccharose, 3: Mannose, 4: Galactose, 5: Amidon, 6: Ellobiose, 7: Leuvulose, 8: Lactose, 9: Sorbose, 10: Adonitol, 11: Inositol, 12: Duilactol, 13: Cellobiose, a: Man Ragosa Sharpe, d: Kempler and Mc Kay a: Lactobacillus plantarum, b: Lactobacillus, c: Lactobacillus plantarum, d: Leuconostoc desctranicum, e: Streptococcus. f: Lactococcus g: Enterococcus sp, h: Lactococcus

Table 5: Characteristics of LAB Strains Isolated From El-Hammoum
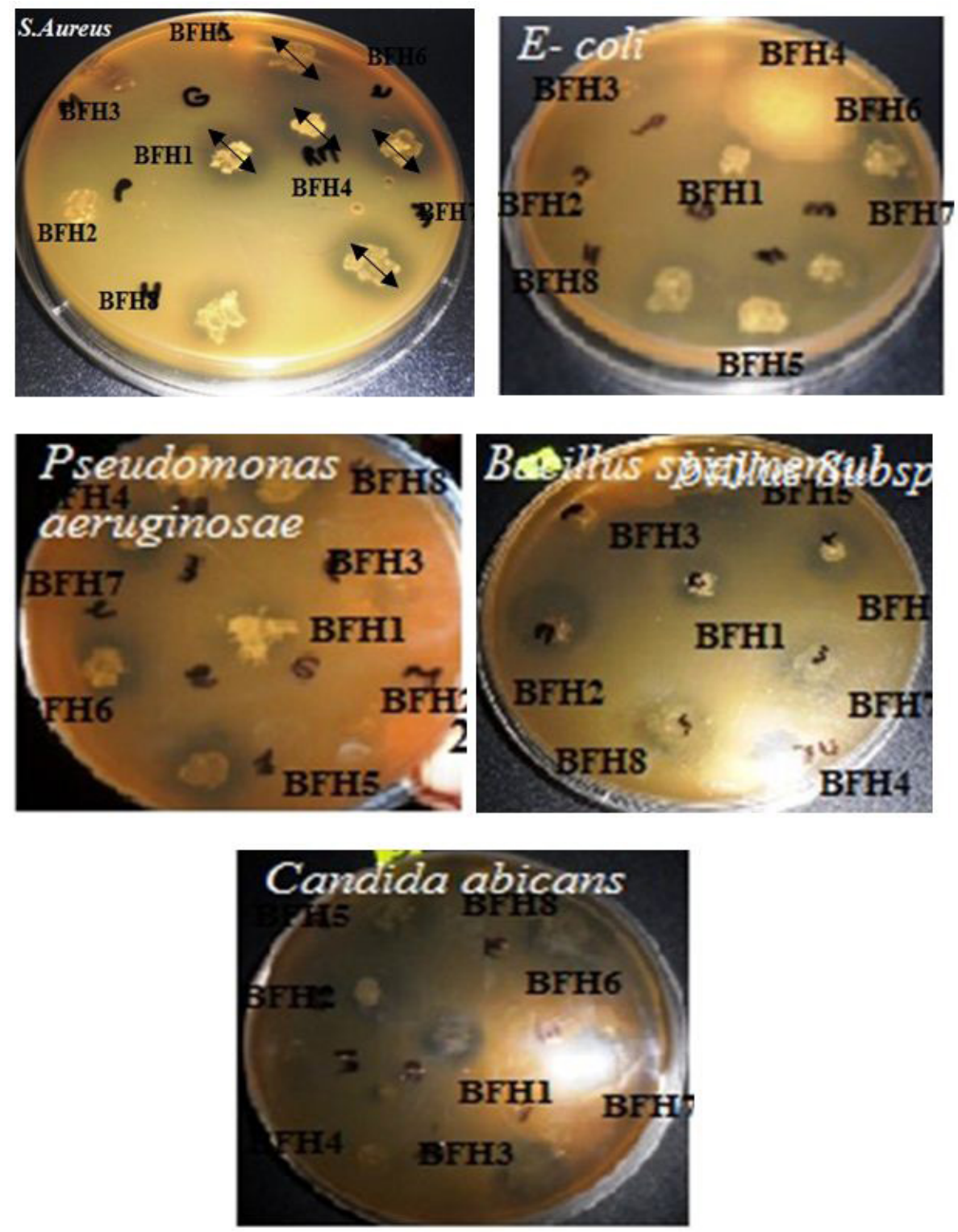

*: FWH1, FWH3: Lactobacillus plantarum - FWH2: Lactobacillus - FWH4: Leuconostoc desctranicum - FWH5: Streptococcus. FWH6, BFWH8: Lactococcus-. FWH7: Enterococcus sp

FWH: Fermented Wheat El-Hammoum

Figure 14: Example Halo of Inhibition Observed in Vitro Antagonism Test: *lactic acid bacteria / Escherichia coli, Bacillus

Subtilis, Staphylococcus aureus, Pseudomonas aeruginosa, Proteus, Escherichia coli, and Candida Albicans 


\section{Conclusions}

In conclusion, the lactic acid bacteria originally isolated from durum wheat (triticum durum) storage in underground silos matmour in regions of "Ain Fareh" Mascara Algeria, are the best candidates for improving the microbiological safety of traditional fermented foods because they are well adapted to the condition of storage (climatic conditions: $\mathrm{T}^{\circ}, \mathrm{ph}, \mathrm{aw}$, and $\mathrm{presence} \mathrm{co}_{2} \ldots .$. ), and should be more competitive than lactic acid bacteria from other sources. All these important changes suffered by the wheat during the fermentation in matmora induced improvements in the organoleptic, nutritional and health so that El-Hammoum stands out as functional and bioactive food. The set of results obtained in our study is a first approach to evaluation the nutritional microbiological and therapeutic effect of fermented wheat product of the Algerian country in some rural area, which is unknown in international country. In perspective, it would be interesting to focus research targeting: The mix of different enzymatic activities carried evidences; the study of volatile and aromatic substances synthesized during fermentation, genetic identification for strains and probiotic properties of lactic acid bacteria isolates (bacteriocins substances).

\section{References}

1. Bar C (2001) Contrôle de la qualité des céréales et des protéagineux. (Guide pratique): Ed, ITFC céréaliers de France, Paris, 253.

2. Djermoun A (2009) La production céréalière en Algérie: les principales caractéristiques. Nature et Technologie 01 : 45-53.

3. Bartali EHS, Persoons E (1989) Stockage des céréales dans des entrepôts souterrains. In « Céréales en régions chaudes »: AUPELF-UREF (Ed.). Edition John Libbey Eurotext, Paris 27-38.

4. Bartali EH (1987) "underground storage pits in morocco", tunnelling and underground space technology (nova york, oxford) 2: 381-3.

5. el-Tayeb Abdalla A, Stigter CJ, Mohamed HA, Mohammed AE, Gough MC (2001) "Effects of wall linings on moisture ingress into traditional grain storage pits": Inter J Biometeorol 4: 75-80.

6. Bartali EH (1995) “Systèmes de stockage traditionnels 'matmoras' et 'sellas", Hommes, Terre et Eaux: Revue Marocaine des Sciences et Techniques du Devéloppement Rural, $25: 16-22$.

7. Bakhella M, Kaanana A, Baba M (1993) "Effect of underground storage on some chemical and rheological properties of wheat": al-awamia, revue marocaine de la recherche agronomique 83: 5-28

8. Dejene MJ, Sigvald R (2004) “The impact of storage methods on storage environment and sorghum grain quality”. Seed Science and Technology 32: 511-29.

9. Aubert C (1985) Les aliments fermentés traditionnels, Ed. Terre Vivante, Paris, 252.

10. Hopkins ES, et Ripley PO (1951) L’ensilage, mais vient au premiers rang des plantes fourragères cultivées pour l’ensilage au canada. Ministère de l'agriculture. Ottawa, canada.

11. Vieira-Dalodé G, Jespersen L, Hounhouigan J, Moller PL, Nago CM, et al. (2007) Lactic acid bacteria and yeasts associated with gowé production from sorghum in Bénin. J Appl Microbiol 103: 342-9.

12. Abdelbasset M, Djamila K (2008) Antimicrobial activity of autochthonous lactic acid bacteria isolated from Algerian traditional fermented milk "Raï". African J Biotechnol 7: 2908-14.

13. Blanco Jose L, Dominguez L, Gomez-Lucia E, Garayzobal JFF, Goyache J et Suarez G (1988) Experimental aflatoxin production in home made yoghurt. Z Lebensm Unters Forsh 186: 323-6.

14. Stiles ME (1996) Biopreservation by lactic acid bacteria. Antonie Van Leeuwenhoek 70: 331-45.

15. Cogan TM, Barbosa M, Beuvier E, Fernandes I, Gomez J, et al. (1997) Characterization of lactic acid bacteria in artisanal dairy products: J Dairy Res 64: 409-21.

16. Cocolin L, Foschino R, Comi G, Grazia Fortina M (2007) Description of the bacteriocins produced by two strains of Enterococcus faecium isolated from Italian goat milk. Food Microbiol 31: 753-8.

17. Heikkila MP, Saris PEJ (2003) Inhibition of Staphylococcus aureus by the commensal bacteria of human milk: J Applied Microbiol 95: 471-8.

18. Chekroun AA, Bensoltane O, Kheroua D, Saidi (2006) Biotechnological characteristics of fermented milk by bacterial associations of the strains Streptococcus, Lactobacillus and Bifidobacteria. Egypt J of Appl Sci 21: 583-98.

19. Sharpe ME (1979) Identification of lactic acid bacteria. In: Skinner F.A., Lovelock D.W., (ED), identification methods for microbiologists Academic Press, London 233-59.

20. Godon JJ, Delorme C, Ehrlich SD, Renault P (1992) Divergence of genomic sequences between Lactococcus lactis subsp. lactis and Lactococcus lactis subsp. Cremoris. Appl Environ Microbiol 58: 4045-7.

21. Kempler GM, Mac Kay LL (1980) Improved medium for detection of citrate fermenting Streptococcus lactis subsp. Diacetylactis. Appl Environ Microbiol 39: 926-7.

22. Guessas BF, Adjoudj Hadadji M, Kihal M (2012) Isolation and identification of Lactic Acid Bacteria from Dhan, a Traditional Butter and Their Major Technological Traits. World Applied Science J 4: 480-8.

23. Samelis J, Maurogenakis F, Metaxopoulos J (1994) "Characterization of lactic acid bacteria isolated from naturally fermented Greek dry salami. Inter J Food Microbiol 23: 179-96.

24. Herrero MB, Mayo B, Gonzalez B, Suarez JE (1996) "Evaluation of technologically important traits in lactic acid bacteria isolated from spontaneous fermentation". J Appl Bacteriol 81: 565-70.

25. Fleming HP, Erchell JL, Caslilow RN (1975) Microbiol inhibition on isolate Pediococcus from cucumber bune. Applied Environ Microbiol 30: 1040-2.

26. Tahara T, Kanatani K (1996) Isolation, partial characterization and mode of action of acidocin J 1229, a bacteriocin produced by Lactobacillus acidophilus JCM 1229. J Applied Bacteriol 81: 669-77.

27. Mathur SR, Singh (2005) Antibiotic resistance in food lactic acid bacteria-a review. Int J Food Microbiol 105: $281-95$.

28. Carr FJ, chill D, Maida N (2002) The lactic acid Bacteria A Literature Survery Critical. Rev Microbiol 28: 281-370. 
29. Axelsson L (2004) Lactic acid bacteria: classification and physiology In: Lactic acid bacteria. Microbiological and functional aspects (eds: Salminen S, von Wright A, and Ouwehand AC). Third edition Marcel Dekker Inc New York: 1-66.

30. Björkroth J, Holzapfel W ( 2006) Genera Leuconostoc, Oenococcus and Weissella. The prokaryotes 4: 267-319.

31. Joseph-Pierre G (2003) Microbiologie Alimentaire. Dunod, Paris.

32. Prescott LM, Harley JP, Klein DA (2010) Microbiologie: 3éme Edition. De boeck 1216

33. Whitman William B (2012) Bergey's Manual of systematic bacteriology. Second Edition, Springer 1450.

34. Chandan Ramesh C, Kilara A (2013) Manufacturing yoghurt and fermented milks. Second Edition, Wiley Blackwell.

35. Fuquay John WF, Fox P (2011) Encyclopedia of dairy sciences. Academic Press: 3200.

36. Yao AA, Egounlety M, Kouame LP, Thonart P (2009) Les bactéries lactiques dans les aliments ou Boissons amylacés et fermentés de l’Afrique de l'Ouest: leur utilisation actuelle. Ann Méd Vét 153: 54-65.

37. De Vuyst L, Vancanneyt M (2006) Biodiversity identification of sourdough lactic acid bacteria: Food. Microbiol $24: 120-7$.

38. Mami A, Boumehira AZ, Rizk HA, Hamedi E, Kihal M ( 2012) Screening of autochthonous Lactobacillus species from Algerian raw goats' milk for the production of bacteriocin-like compounds against Staphylococcus aureus: African J Microbiol Rese 6: 2888-98.

39. Sharaf FE, Mogbel AHR (2011) Isolation, identification and antimicrobial activity of some local isolates of Lactic acid bacteria. J Microbiol Res 1816-4935.

40. Cintas LM, Casaus P, Holo H, Hernandez PE, Nes IF, et al. (1998) Enterocins L50A and L50B two novel bacteriocins from Enterococcus faecium L50, are related to staphylococcal hemolysins. J Bacteriol 180: 1988-94.

41. Ayad EHE, Nashat S, El-Sadek N, Metwaly H, El-Soda M (2004) Selection of wild lactic acid bacteria isolated from traditional Egyptian dairy products according to production and technological criteria. Food Microbiol 21: 715-25.

42. Mezaini A, Chihib NE, Bouras AD, Nedjar-Arroume N, Hornez JP (2009) Antibacterial activity of some lactic acid bacteria isolated from an Algerian dairy product. J Environmental and Public Health doi: 10.1155/2009/678495.

43. Leyral G, Vierling E (2007) Microbiologie et toxicologie des aliments: Hygiène et sécurité alimentaires $4^{\text {ème }}$ édition. Edition Doin Paris 287.

44. Favre G (2004) Prébiotiques et probiotiques: ont-ils un réel intérêt pour la santé ? Rôle du pharmacien dans leur conseil à l'officine, Thèse de doctorat: Pharmacie. Grenoble: Université JOSEPH FOURIER 84.

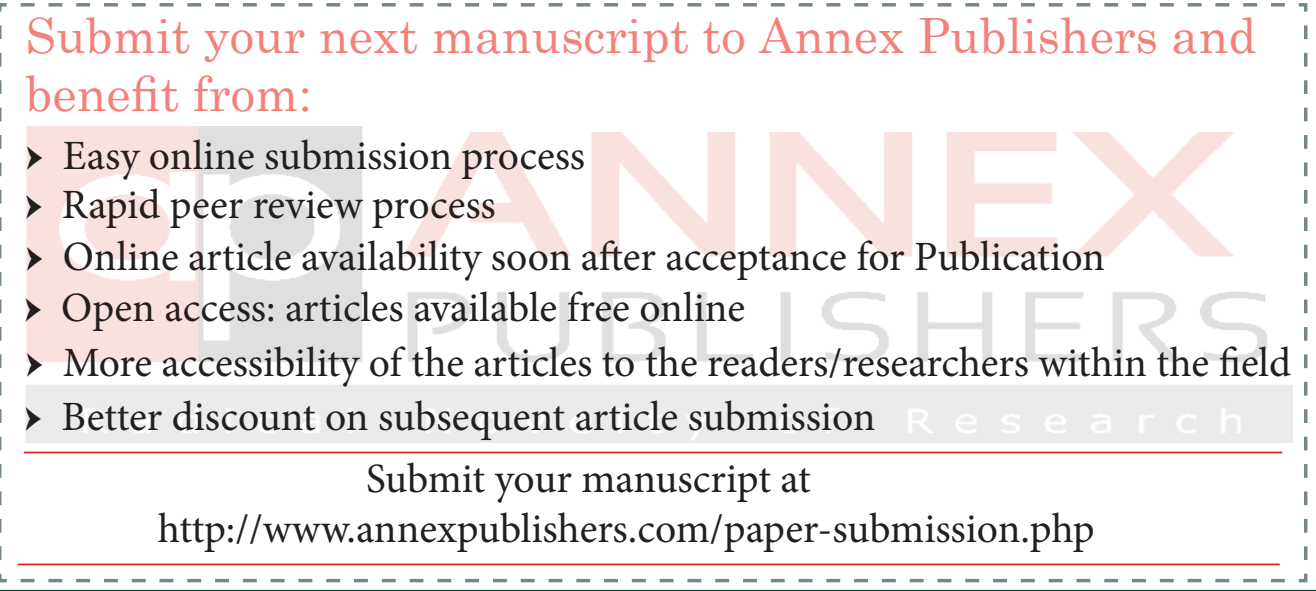

